\title{
Leukocyte count in COVID-19: an important consideration
}

\author{
Samah Selim(1)
}

To the Editor,

Dear Sir,

In December 2019, an outbreak of pneumonia associated with high mortality was noticed in Wuhan city, China. Thereafter, the World Health Organization (WHO) confirmed the novel coronavirus named SARS-CoV-2 was responsible for the clinical features and declared this as COVID-19 [1].

The virus attaches to angiotensin-converting enzyme-2 (ACE) receptors on various types of cells including type 2 pneumocytes, renal epithelial cells, and lymphocytes. Furthermore, the virus can lead to exaggerated inflammatory response known as cytokine storm that is characterized by increased interleukin (IL)-2, IL-7, granulocyte colonystimulating factor (GCSF), interferon- $\gamma$ inducible protein 10 , monocyte chemo-attractant protein-1, macrophage inflammatory protein $1-\alpha$, and tumor necrosis factor- $\alpha$. It is responsible for the development of acute respiratory distress syndrome (ARDS) and multiple organ failure [24].

Several studies demonstrated that neutrophilia that might be related to the cytokine storm (absolute neutrophil count above the normal range; $3-7.5 \times 10^{9} / \mathrm{L}$ ) and/or lymphocytopenia (lymphocyte count $<1.5 \times 10^{9} / \mathrm{L}$ ) were present in severe cases of COVID-19 pneumonia and were associated with poor prognosis. Neutrophil to lymphocyte ratio (NLR) has also been found to predict disease severity in the early stages of SARS CoV-2 infection. In contrast, small studies reported a significant reduction in granulocytes in severe as compared to non-severe patients [5].

In conclusion, from the previous evidence, the following points should be taken in consideration:

1. Patients with COVID-19 pneumonia may have normal $\left(4-11 \times 10^{9} / \mathrm{L}\right)$, low, or high leukocyte count.

Correspondence: samah.selim@ymail.com

Departrment of Chest Diseases, Faculty of Medicine, Cairo University, Cairo, Egypt

(c) The Author(s). 2020 Open Access This article is licensed under a Creative Commons Attribution 4.0 International License, which permits use, sharing, adaptation, distribution and reproduction in any medium or format, as long as you give appropriate credit to the original author(s) and the source, provide a link to the Creative Commons licence, and indicate if changes were made. The images or other third party material in this article are included in the article's Creative Commons licence, unless indicated otherwise in a credit line to the material. If material is not included in the article's Creative Commons licence and your intended use is not permitted by statutory regulation or exceeds the permitted use, you will need to obtain permission directly from the copyright holder. To view a copy of this licence, visit http://creativecommons.org/licenses/by/4.0/. 


\section{Consent for publication}

Not applicable

\section{Competing interests}

Not applicable

Received: 11 August 2020 Accepted: 6 November 2020

Published online: 18 November 2020

\section{References}

1. He F, Deng Y, Li W (2020) Coronavirus Disease 2019 (COVID-19): what we know? J Med Virol 92(7):719-725. https://doi.org/10.1002/jmv.25766

2. Huang C, Wang Y, Li X, Ren L, Zhao J, Hu Y et al (2020) Clinical features of patients infected with 2019 novel coronavirus in Wuhan, China. Lancet 395: 497-506

3. Li X, Geng M, Peng Y, Meng L, Lu S (2020) Molecular immune pathogenesis and diagnosis of COVID-19. J Pharm Anal 10(2):102-108. https://doi.org/10. 1016/j.jpha.2020.03.001

4. Rothan HA, Byrareddy SN (2020) The epidemiology and pathogenesis of coronavirus disease (COVID-19) outbreak. J Autoimmun 109:102433

5. Khartabil TA, Russcher H, van der Ven A, de Rijke YB (2020) A summary of the diagnostic and prognostic value of hemocytometry markers in COVID19 patients. Critical Reviews in Clinical Laboratory Sciences. https://doi.org/ 10.1080/10408363.2020.1774736

\section{Publisher's Note}

Springer Nature remains neutral with regard to jurisdictional claims in published maps and institutional affiliations.

\section{Submit your manuscript to a SpringerOpen ${ }^{\circ}$ journal and benefit from:}

- Convenient online submission

- Rigorous peer review

- Open access: articles freely available online

- High visibility within the field

- Retaining the copyright to your article 